\title{
Assessment of Physicochemical Properties and Heavy Metals in Borehole Water Used For Drinking In Okada Town, Edo State, Nigeria
}

\author{
*11RAJI, WA; ${ }^{2}$ ANIH, CE; ${ }^{1}$ OBETA, PO \\ ${ }^{1}$ Chemical and Petroleum Engineering Department, Igbinedion University, Okada. Nigeria \\ ${ }^{2}$ Chemical Engineering Department, Federal University of Petroleum Resources, Effurun. \\ *Corresponding Author Email: raji.wuraola@iuokada.edu.ng
}

\begin{abstract}
The consumption of unsafe water is detrimental to human health. It is therefore important to ascertain the quality and purity of water set out for drinking. This paper investigates the physiochemical properties of drinking water obtained from boreholes located at various sites in Okada town, Nigeria. The assessment of physicochemical properties and heavy metal contents of groundwater (borehole) quality were evaluated. Ten water samples labeled A-J were collected from boreholes at different locations in Okada community and subjected to laboratory test to determine the $\mathrm{pH}$, biological oxygen demand (BOD), chemical oxygen demand (COD), dissolved oxygen (DO), hardness, turbidity, total organic carbon, total dissolved solids, electrical conductivity, and concentration of phosphates, nitrates, lead, sodium, calcium and chloride. The $\mathrm{pH}$ in the water samples is an indication of acidity and the WHO standard for $\mathrm{pH}$ value is specified within the range of 6.5-8.5. However the $\mathrm{pH}$ values obtained for the samples are $\mathrm{A}(4.37), \mathrm{B}(4.44), \mathrm{C}(5.06)$, $\mathrm{D}(4.86), \mathrm{E}(6.40), \mathrm{F}(4.25), \mathrm{G}(5.95), \mathrm{H}(4.53), \mathrm{I}(6.61)$ and $\mathrm{J}(5.70)$. This implies that only the sample I of $\mathrm{pH}$ value 6.61 falls within the WHO standard and safe for drinking. Thus, the water from the community can only be considered safe to drink except a neutralizing filter is incorporated into the water system in other to avert the implications of consuming acidic water.
\end{abstract}

DOI: https://dx.doi.org/10.4314/jasem.v23i12.19

Copyright: Copyright (C) 2019 Raji et al. This is an open access article distributed under the Creative Commons Attribution License (CCL), which permits unrestricted use, distribution, and reproduction in any medium, provided the original work is properly cited.

Dates: Received: 30 November 2019; Revised: 20 December 2019; Accepted: 23 December 2019

Keywords: borehole, physicochemical-parameters, chemical-oxygen-demand, dissolved- oxygen

The quality of water over the decade had been described by the colorless, odorless, tasteless and its transparent character. It is a basic resource necessary for sustaining all human activities, so its provision in desired quantity and quality is of utmost importance (Taruna and Alankrita, 2013). The two major sources of freshwater are the surface water and groundwater. The groundwater provides a valued fresh water resource to human population and constitutes about two-third of the fresh water reserves presently occupying various spaces across the world (Adeyemi, et al., 2017). The deterioration of water quality has led to the destruction of ecosystem balance, contamination of soil and surface water sources (Faiza, et al., 2018). The physical, chemical, and biological parameters were often used to determine the safety of water required for consumption (Sivaranjani et al., 2015; Muhammad et al., 2013; Gorde and Jadhav, 2013; Sasikaran, 2012; Loukas, 2010; Julia, et al., 2006). Most developing and underdeveloped economy are faced with the challenge of lack of adequate, clean and safe water supply infrastructures. Nigeria, as a developing country is also striving hard to supply potable drinking water especially in rural areas where most people depend on ground and surface water for sustenance. Over the years the Nigerian government had put in place policies that could encourage the priority for the provision of safe, clean and adequate water especially in the rural areas, however the implementation of such policies was overwhelmed by the inadequacies of implementation of such policies (Nwankwoala, 2011). Groundwater is often the first alternative choice of many consumers due to its perceived cleanness and safeness. However, many studies have shown that groundwater can appear clean but contains a wide variety of contaminants (Olasoji et al., 2019; Vijaya and Sai, 2017; Sabrina et al., 2013; Muhammad et al., 2013; Rossiter et al., 2010). An estimated $80 \%$ of all diseases and over one-third of deaths in developing countries are caused by the consumption of contaminated water and on average as much as one-tenth of each person's productive time is sacrificed to water-related diseases (WHO,2011). Groundwater contamination occurs when pollutants are released and make their way down into the ground (Adeyemi et al., 2017). Main sources of groundwater contamination are from mine dumps, leach residue, landfills, leaking septic tanks, oil spillage, acid rain and host rock in which it is dug. Hence, the location of a borehole yet to be drilled should be well assessed in other to avoid water pollution that can pose as a threat to human lives. Contaminants such as heavy metals, 
lead, arsenic, chromium, cadmium and mercury are dangerous for human health when consumed at high concentration because they are toxic and can be carcinogenic (Doan et al., 2018; Malaysia et al., 2015; Sabrina et al., 2013; Mohod and Dhote, 2013; Balachandar, 2010). Owing to changes in environmental factors, a continuous water quality assessment should be carried out for provision of necessary information on the water quality and its suitability for domestic use. The objective of this paper is to assess the quality of water obtained for domestic consumption in Okada community of Edo State, south-south Nigeria by evaluating the physicochemical properties and heavy metal contents.

\section{MATERIALS AND METHOD}

Description of the Sampling Site: Okada is a town in the Ovia North-East local government area of Edo state Nigeria. The town geographical coordinate is $6^{\circ}$ 44' 0" North, 5'23' 0" East. Okada town host a University campus, a teaching hospital, commercial banks and quantifiable business activities with a residential population of 65,000 (John, 2017). In view of this, the analysis of water consumption in the community cannot be over emphasized. The map of Edo State showing the sample site is shown in figure 1 (Orjiekwe et al., 2013).

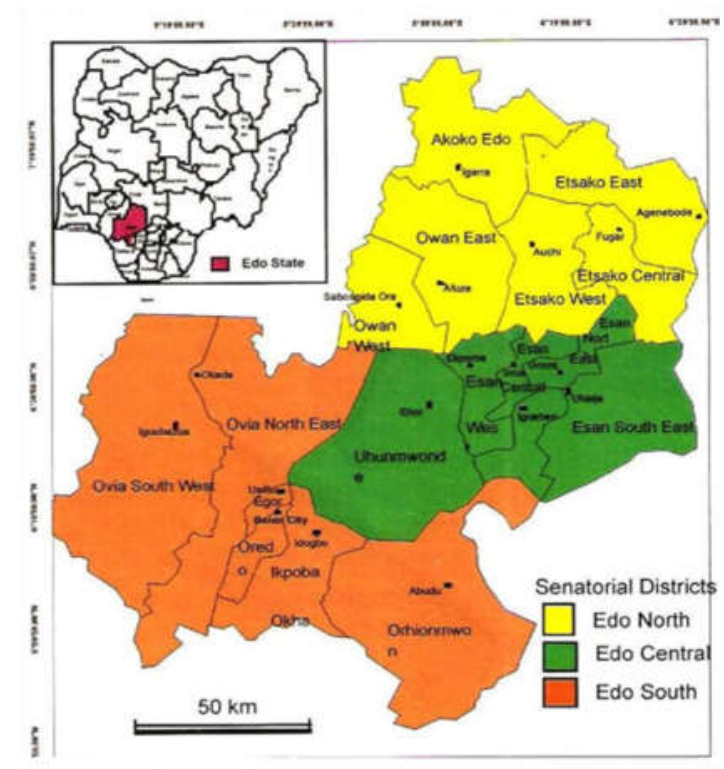

Fig 1. Map of Edo state showing the study area (Source: Orjiekwe et al., 2013)

Method: A simple random cross-sectional sampling was carried out to collect water samples from ten boreholes at different locations to obtain a good distribution of the study area in Okada town, for purpose of evaluating the overall quality of water obtained from the sources. The samples were collected in cleaned plastic polyethylene bottles and controlled to avoid unusual contamination that might influence the site water characteristics. Prior to the sampling, all the bottles were washed and rinsed thoroughly with distilled water before taking samples. The physical and chemical parameters analyses were carried out following standard procedure set by APHA 2012 for examining water. The $\mathrm{pH}$ of the water samples were measured using PHS-25 desktop $\mathrm{pH}$ meter. Complexometric titration was used to determine total hardness. The values of sulphate, phosphate and turbidity were determined by WGZ-1A table top turbidity meter. The alkaline metals of calcium and sodium were analyzed using HANNA HI-83200 multi-parameter photometer. OOTDTY 8WF0066 water quality detector was used to determine the COD and the DO was determined using portable DO meter. A multi-factor water test quality strips were used to determine nitrate, nitrite and chlorides. All the reagents used were of analytical grade.

\section{RESULTS AND DISCUSSION}

The physical and chemical parameters of water samples were analyzed and results obtained were compared to WHO standard. The results of the physiochemical parameters obtained from the analysis is as tabulated in Table 1.

Quality by $\mathrm{pH}$ value: Potential hydrogen $(\mathrm{pH})$ refers to how much hydrogen is mixed with water and it indicates the alkalinity or acidity of water on a logarithmic scale on which 7 is neutral. The $\mathrm{pH}$ values below and above 7 are acidic and alkaline respectively. The acceptable $\mathrm{pH}$ value for drinking water is between the range 6.5-8.5 as specified by WHO. Comparison of the $\mathrm{pH}$ value of the samples explicitly revealed the acidic nature of the water provided for consumption in the study community except with sample I which falls within the standard specified and considered good for consumption. The acidity of the water samples could be as a result of increase in temperature, high concentration of carbon dioxide in water due to global warming and acid rain . Consumption of acidic water is dangerous to human health because it makes the blood acidic by forming carbonic acid in the body system. Therefore, groundwater from Okada town should be treated before consumption.

Quality by oxygen demand analysis. (BOD, COD and $D O)$ : Biological oxygen demand (BOD) is the measure of the quantity of oxygen consumed in the course of aerobic processes of decomposition of organic materials caused by microorganisms while chemical oxygen demand (COD) is the total amount of oxygen required to chemically oxidize both the biodegradable and non-biodegradable organic matter. BOD determines how organic matter affects the 
concentration of dissolved oxygen (DO) in water. Generally, a high BOD and COD indicates a high content of easily degradable and non-degradable organic matter in the water sample and this causes a decline in DO due to high demand of oxygen by the bacteria feeding on the organic material. In Table 1, it was observed that BOD and COD values obtained from all the water samples are below the WHO standard while DO values are above. This implies that, there is no significant organic material present in the water to be decomposed by bacteria resulting to availability of enough oxygen in all the samples making the water safe for consumption. The values of hardness, turbidity, total organic carbon (TOC) total dissolved solids, electrical conductivity and salinity are all within the allowable limit value of WHO standard. Table 2 shows the concentration of heavy metal in water sample collected from Okada town.

Table 1: Physicochemical parameters of water samples collected from Okada town

\begin{tabular}{|c|c|c|c|c|c|c|c|c|}
\hline Samples & pH value & $\begin{array}{l}B O D \\
m g / l\end{array}$ & $\begin{array}{l}C O D \\
m g / l\end{array}$ & $\begin{array}{l}D O \\
m g / l\end{array}$ & $\begin{array}{l}\text { Hardness } \\
\mathrm{mg} / \mathrm{l}\end{array}$ & $\begin{array}{l}\text { TURBI } \\
N T U\end{array}$ & $\begin{array}{l}\text { TOC } \\
m g / l\end{array}$ & $\begin{array}{l}T D S \\
m g / l\end{array}$ \\
\hline A & 4.37 & 5.14 & 1.5 & 5.94 & 3 & 2.4 & 1.8 & 78 \\
\hline B & 4.44 & 3.78 & 1.2 & 5.85 & 0 & 2.1 & 1.8 & 25 \\
\hline $\mathrm{C}$ & 5.06 & 4.16 & 1.2 & 5.91 & 0 & 2.3 & 1.7 & 20 \\
\hline $\mathrm{D}$ & 4.86 & 3.62 & 1.1 & 6.05 & 7 & 2.7 & 2 & 21 \\
\hline $\mathrm{E}$ & 6.4 & 3.83 & 1.3 & 5.94 & 6 & 2.3 & 2 & 23 \\
\hline $\mathrm{F}$ & 4.25 & 3.18 & 1.4 & 5.92 & 0 & 2.4 & 1.9 & 12 \\
\hline G & 5.95 & 3.05 & 1.2 & 5.91 & 0 & 2.6 & 1.7 & 17 \\
\hline $\mathrm{H}$ & 4.53 & 4.37 & 1 & 6.02 & 0 & 2.6 & 1.7 & 29 \\
\hline I & 6.61 & 4.21 & 1.4 & 5.86 & 0 & 3 & 2.2 & 27 \\
\hline $\mathrm{J}$ & 5.7 & 3.96 & 1 & 6.01 & 0 & 2.1 & 1.7 & 17 \\
\hline WHO & $6.5-8.5$ & 6 & 10 & 5 & 200 & 5 & 25 & 1200 \\
\hline
\end{tabular}

\begin{tabular}{|c|c|c|c|c|c|c|c|c|c|c|}
\hline Samples & $\begin{array}{l}\mathrm{PO}^{2+}{ }_{4} \\
\mathrm{mg} / \mathrm{l}\end{array}$ & $\begin{array}{l}\mathrm{PO}^{3+}{ }_{4} \\
\mathrm{mg} / \mathrm{l}\end{array}$ & $\begin{array}{l}\mathrm{Na} \\
\mathrm{mg} / \mathrm{l}\end{array}$ & $\begin{array}{l}\mathrm{NH}_{2} \mathrm{~N} \\
\mathrm{mg} / \mathrm{l}\end{array}$ & $\begin{array}{l}M n \\
m g / l\end{array}$ & $\begin{array}{l}\mathrm{Pb}^{2+} \\
\mathrm{mg} / \mathrm{l}\end{array}$ & $\begin{array}{l}\mathrm{Ca}^{2+} \\
\mathrm{mg} / \mathrm{l}\end{array}$ & $\begin{array}{l}\mathrm{NO}_{2}^{-} \\
m g / l\end{array}$ & $\begin{array}{l}\mathrm{NO}_{3}^{-} \\
\mathrm{mg} / \mathrm{l}\end{array}$ & $\begin{array}{l}\mathrm{Cl}^{-} \\
\mathrm{mg} / \mathrm{l}\end{array}$ \\
\hline $\mathrm{A}$ & 0.43 & 0 & 30 & 0 & 0 & 0 & 4.72 & 0.01 & 2.5 & 3 \\
\hline B & 0.32 & 0 & 50.1 & 0 & 0 & 0 & 3.81 & 0.01 & 5 & 3 \\
\hline $\mathrm{C}$ & 0.21 & 0 & 29.7 & 0 & 0 & 0 & 3.54 & 0.01 & 5 & 3 \\
\hline $\mathrm{D}$ & 0.29 & 0 & 10.5 & 0 & 0 & 0 & 4.03 & 0.01 & 5 & 0 \\
\hline E & 0.45 & 0 & 45.2 & 0 & 0 & 0 & 3.27 & 0.01 & 2.5 & 3 \\
\hline $\mathrm{F}$ & 0.71 & 0 & 38.3 & 0 & 0 & 0 & 2.4 & 0 & 2.5 & 0 \\
\hline G & 0.2 & 0 & 60.2 & 0 & 0 & 0 & 3.82 & 0 & 5 & 3 \\
\hline $\mathrm{H}$ & 0.48 & 0 & 47.4 & 0 & 0 & 0 & 3.71 & 0.01 & 5 & 5 \\
\hline I & 0.44 & 0 & 38.3 & 0 & 0 & 0 & 4.02 & 0.01 & 5 & 3 \\
\hline $\mathrm{J}$ & 0.29 & 0 & 39 & 0 & 0 & 0 & 3.6 & 0.01 & 5 & 3 \\
\hline WHO & 5 & - & 200 & 0.5 & 0.05 & 0.01 & 200 & 3 & 45 & 250 \\
\hline
\end{tabular}

The permissible limit set by WHO for Lead in drinking water is $0.01 \mathrm{mg} / 1$. In all the samples analyzed, it is observed that no trace of lead was found. This is as a result of non-lead related anthropogenic activities in the selected areas of the community such as mining practices, improper disposed of batteries, industrial wastes, smelting facilities and zero leachate of lead from the plumbing materials. Thus, the water from Okada community town is safe for drinking.

Quality by Phosphates, Nitrates and Manganese contents: Phosphate is not harmful to humans but too much of it in drinking water speeds up eutrophication which in turn reduces the water DO. In table 2 , it is observed that the concentration of phosphate in the samples range between $0.20-0.70 \mathrm{mg} / \mathrm{L}$ which is below the permissible limit specified by WHO in drinking water. Nitrate is an inorganic compound that is found in groundwater through septic systems and fertilizers run-off. Nitrate naturally does not pose a threat except when it is reduced to nitrites. Presence of nitrates in drinking water above $45 \mathrm{mg} / \mathrm{L}$ causes "blue baby" disease in infants according to WHO standard. The highest concentration of nitrates recorded in the samples is $5.00 \mathrm{mg} / \mathrm{l}$ which is within the acceptable limit set by WHO standard. Nitrates low concentration could be as a result of low farming activities in the selected area which could result to release of nitrates from fertilizers.

Human exposure to manganese concentrations higher than $0.05 \mathrm{mg} / \mathrm{l}$ in water can lead to severe disorders in nervous system, memory loss and depression as specified by WHO. Manganese was not found in the water samples analyzed from Okada community town.

Quality by Calcium, Sodium and chloride contents: Sodium is important for proper functioning of the body by regulating blood pressure and flow but it can create concerns when it appears at high concentration in drinking water. The WHO standard for sodium in drinking water on the basis of taste is $200 \mathrm{mg} / \mathrm{l}$. Although, the intake of sodium varies in individuals 
associated with heart and kidney problems. It is worthy to note that sodium concentration in all the water samples in this work are within the WHO standard. Calcium is considered to be an essential nutrient for healthy growth and protection of bones. It prevents blood coagulation, reduces stress, weariness and improves immunity. Insufficient calcium in the body causes migraine, brittle nails and weak bones while excessive supply can result to kidney stones. According to WHO standard, the highest desirable level of calcium in water is $75 \mathrm{mg} / 1$. The maximum concentration of calcium in all the samples analyzed was $4.07 \mathrm{mg} / \mathrm{l}$ (sample A), this implies that Okada groundwater is soft and it is within the WHO guidelines. Chloride occurs naturally as elements and it is common in natural water. Chloride in drinking water is not harmful, however, higher concentration above 250mg/1 can cause unpleasant taste and corrosion which results to leaching of metals from the pipes used for water system distribution. The chloride levels in all water samples obtained are within the permissible limit of WHO standard.

Conclusion: This study assessed the physicochemical properties and heavy metal contents of groundwater from boreholes in different locations in Okada town community. Ten water samples were collected from different locations in the study area for laboratory analysis. The results obtained shows that the concentrations of the properties of water were found to be within the recommended limits of WHO standard with key exception of $\mathrm{pH}$. All the water samples have $\mathrm{pH}$ values below the set limits of WHO except sample I. The study exposes the need for the neutralization of the borehole water mostly consumed for drinking in Okada town due to its acidic nature. Further examination could be carried out to assess the biological properties of the borehole water.

Acknowledgements: The authors would like to thank Ikinbor Ebinare Eric and Ahmad Abdulhamid Jubrin for the support in data collection. The appreciation is also extended to Luco Scientific Laboratory for the analysis of the water samples.

\section{REFERENCES}

Adeyemi, O; Opeyemi , A; Olufemi , D (2017). Groundwater: Quality Levels and Human Exposure, SW Nigeria. Journal of Environmental Geography. 10 (1-2); 23-29

APHA (2012) Standard Methods for the Examination of Water and Waste Water. 22nd Edition, American Public Health Association, American Water Works Association, Water Environment Federation
Balachandar, D ; Sundararaj, P; Rutharvel, MK; Kumaraswamy, K (2010). An investigation of ground water quality and its suitability to irrigated agriculture in oimbatore District, Tamil Nadu, India- A Gis Approach. International Journal of environmental sciences. 1(2): pp.176-190

Doan, NH; Lo, VT; Duong, KV; Ta, TB; Ha, LP; Nguyen, DT; Nguyen, DS; Hoang, TG; Nguen, MH; Pham, MK (2018). Lead Environmental Pollution and Childhood Lead Poisoning at Ban Thi Commune, Bac Kan Province, Vietnam. BioMed Research International. 1: 1-7

Faiza ,T; Yenny, R, Sasmito ,D; Bagyo, Y; Amin ,SL (2018).The Analysis of the Physical and Chemical Properties of the Water Quality in the Rainy Season in the Sumber Maron River - Kepanjen, Malang -Indonesia, Resources and Environment. 8(1): $1-5$

Gorde, S. P., Jadhav, M. V. (2013). Assessment of Water Quality Parameters: A Review Int. Journal of Engineering Research and Applications, 3(6):2029-2035

John, MD (2017). Public Perception of Police Activities in Okada, Edo State Nigeria. Covenant J. of Business \& Social Sci. (CJBSS), 8(1): 29-42.

Julia, LB, Szabo, Z; Schneider D., William, DA; Gallagher RA (2006). Mercury in groundwater, septage, leach-field effluent and soils in residential areas, New Jersy coastal plain. Sci. Total Environ. 361:144-162.

Loukas, A., (2010). Surface water quantity and quality assessment in Pinios River,Thessaly, Greece. Desalination, 250(1): 266-273.

Malaysia, NR; Siti, HA; Homayoonfard M; Ali NJ, Rehan M., Sadef Y; Nizami, AS (2015). Analysis of Physiochemical Parameters to Evaluate the Drinking Water Quality in the State of Perak. J. of Chem.Vol. 2015, Article ID 716125: 1-10.

Mohod, CV; Dhote, J (2013). Review Of Heavy Metals In Drinking Water And Their Effect On Human Health. International Journal of Innovative Research in Science, Engineering and Technology. 2(7): 2992-2996.

Muhammad, M; Samira S; Faryal, A; Farrukh, J (2013). Assessment of Drinking Water Quality and its Impact on Residents Health in Bahawalpur City. 
Inter. J. of Humanities and Social Sci.. 3(15):.114128.

Nwankwoala, HO; Ngah, SA (2011).Groundwater Resources of Niger Delta: Quality implications and management considerations. Inter.J. of Water Res. and Environ Engrg. 6(5): 155-163

Orjiekwe, CL; Oguniran, K: Solola, SS (2013). Novel method of iron removal from underground dug well waters in communities around Okada town, Ovia North-East L.G.A. Edo State. International Journal of Physical Sciences 8(28): 1464-1469

Olatunji SO; Nather OO; Bayode, A; Joshua NE (2019). Water Quality Assessment of Surface and Groundwater Sources Using aWater Quality Index Method: A Case Study of a Peri-Urban Town in Southwest, Nigeria. Environments, 6 (23): 1-11

Rossiter, HMA; Owusu, PA; Awuah, E; Macdonald, A; Schäfer, AI (2010). Chemical Drinking Water Quality in Ghana: Water Costs and Scope for Advanced Treatment. The Sci. of the Total Environ. 408: 2378-2386

Sabrina, S, Daniela, P, Joseph MS; Martin, BN; (2013). Assessment of Physical-Chemical
Drinking Water Quality in the Logone Valley (Chad-Cameroon). Sustainability. 5 : 3060-3076.

Sasikaran, S. A. (2012). Physical, Chemical and Microbial analysis of bottled drinking water. The ceylon medical journal. 57: 111-116.

Sivaranjani S; Amitava, R; Samrath, S (2015). Water Quality Assessment with Water Quality Indices. Inter. J. of Biores. Sci. 2(2): 85-89.

Taruna, J; Alankrita, C (2013). Assessment of water quality and its effects on the health of residents of Jhunjhunu district, Rajasthan: A cross sectional study. J. of Public Health and Epidemiology. 5(4): 186-191

Vijaya L; Sai TK (2017). A study on assessment of groundwater quality and it suitability for drinking in Vuyyuru, Krishna (dist.), Andhra Pradesh. Inter. J. of Engrg. Development and Research. 5(2): 1662-1668.

World Health Organization (WHO), Guidelines for Drinking-Water Quality, WHO Press, Geneva, Switzerland, 4th edition, 2011 